\title{
AL-WAṬWĀṬ’S DESCRIPTION OF JEWISH FESTIVALS - PROBING THE SOURCES OF HIS KNOWLEDGE
}

\author{
HAGGAI MAZUZ \\ School of International Studies, Sun Yat-sen University, China \\ Tang Jia Wan, 519082, Zhuhai, P. R. China \\ e-mail: hagaimazuz@gmail.com
}

The Egyptian historian Jamāl al-Dīn Muḥammad b. Ibrāhīm b. Yaḥyā.al-Kutubī, known as al-Waṭwāt (1235-1318 CE), in his Mabāhij al-Fikar wa-Manāhij al-'Ibar, describes seven Jewish festivals. This paper references these descriptions and attempts to trace their provenance. It is found that many of his descriptions are sourced to two earlier Muslim scholars. Some apparent analogies and allusions, however, are found between al-Wațwāṭ's accounts and a broad array of Jewish sources.

Key words: al-Wațāt, Jewish festivals, al-Maqdisī, al-Bīrūnī, Jews of Egypt.

\section{Introduction}

Mediaeval Muslim authors took an immense interest in non-Muslims. Their reasons oscillated between inquisitiveness to polemic. Although many works were written on the topic (e.g., Lazarus-Yafeh 1996; Waardenburg 1999), some texts have remained unstudied. This is the case of the Egyptian historian Jamāl al-Dīn Muhammad b. Ibrāhīm b. Yahyā al-Kutubī, known as al-Wațāt (1235-1318 CE), ${ }^{1}$ one of the earliest historians in the Mamluk period (1250-1517 CE). His best-known work, Mabāhij al-Fikar wa-Manāhij al-'Ibar, is an encyclopaedia of natural sciences and geography. In the ninth chapter of the first section, he discusses festivals of nations, the Jews among them.

Antonella Ghersetti justifiably notes that al-Wațāt has been somewhat neglected in modern scholarship (Ghersetti 2013, p. 72). As a reflection of this, there is no entry on him in the Encyclopaedia of Islam. He briefly describes seven festivals in the following order: Ro'sh ha-Shanah, The Day of Atonement, Festival of Booths,

\footnotetext{
${ }^{1}$ On his life and work, see Ghersetti $(2013 ; 2015)$.
} 
Passover, Pentecost, Purim, and Hanukkah (al-Wațwāt 1990, Vol. 1, pp. 216-218). In the discussion that follows, I describe this account, assess the extent of al-Watwăț's reliance on previous Muslim scholars on this topic, propose Jewish sources of information that may underlie his description, and estimate the influence of his presentation of the Jewish festivals on later Muslim scholars, in an attempt to remedy somewhat the lack of academic interest in this scholar.

\section{Al-Wațwāṭ’s Guide to the Jewish Festivals}

Ro'sh ha-Shanah: Al-Wațāt calls Ro'sh ha-Shanah 'ìd ra's al-sana, a literal translation of the Hebrew, and adds that "They (i.e., the Jews) call it 'id ra's ha-yasha, namely, 'ìd ra's al-shahr" (al-Wațwāt 1990, Vol. 1, pp. 216-217). His words demonstrate that he received a corrupted version of the name of the festival and associates the timing of the first day of the festival with the head of the month (Ro'sh Hodesh). The festival falls on the first day of Tishrei, he says, and its status for the Jews is like

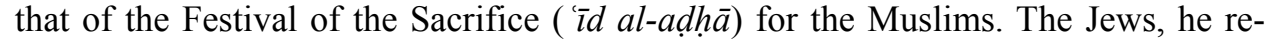
ports, say that Allāh ordered Abraham to sacrifice Isaac on this day, but redeemed him with a great sacrifice (al-Wațaat 1990, Vol. 1, pp. 216-217).

It seems that al-Wațwāt relied somewhat on Kitāb al-Bad' 'wa'l-Ta'rīkh by Muțahhar b. Țāhir al-Maqdisī (10th century CE), ${ }^{2}$ who also called the festival 'i $d r a$ 's al-shahr and used a similar (and more accurate) transliteration of Ro'sh ha-Shanah ( $r \bar{a}$ sh ha-shanā). Alternatively, both borrowed from the same source. Al-Maqdisī also mentions the binding (al-Maqdisī 1907, Vol. 4, p. 37), but al-Wațaât adds that the status of Ro'sh ha-Shanah for the Jews is like the Festival of the Sacrifice for the Muslims and his description of the festival is clearer and better organised than is that of al-Maqdisī.

The Day of Atonement: Al-Wațwāt calls this festival 'ìd șawmārayyā (صوماريا) (al-Wațwāt 1990, Vol. 1, p. 217), possibly due to a mistake in the diacritical mark. The correct word is $r a b b \bar{a}$, i.e., the great fast, a name used for the Day of Atonement in Aramaic in the Jerusalem Talmud (JT) - șomā rabbah (צַוֹ (JT Ro'sh haShanah 8b [1:4]; JT Yōmā 41a [8:4]). The first alif should be part of the word șawmā and the name of the festival should be given in two words (صوما ربا) and not in one word as it appears. Here al-Wațwăt again follows al-Maqdisī who also refers to the fast in this manner, but accurately (al-Maqdisī 1907, Vol. 4, p. 37).

Then al-Wațāt explains that this observance is called al-kibbūr (a corrupted form of the Hebrew name of the fast, Kìppūr), the great fast (al-șawm al- 'azìm) that the Jews were ordered to observe. Those who do not fast are executed. The fast, alWațwăt continues, lasts twenty-five hours. It starts one hour before Tishrei's ninth sunset and ends one hour after it on the tenth. This is why it is sometimes called al'asshür, the tenth (al-Wațaàt 1990, Vol. 1, p. 217). In this part of his account, he

\footnotetext{
${ }^{2}$ On al-Maqdisī's life and work and his account of Jewish festivals, see Adang (1996a, pp. 66-67; 1996b, pp. 259-260).
} 
relied on Kitāb al-Āthār al-Bāqiya 'an al-Qurūn al-Khāliya by Muhammad b. Aḥmad al-Bīrūnī (973-1048 CE), ${ }^{3}$ with two small differences: al-Bīrūnī argues that the fast starts half an hour before Tishrei's ninth sunset and ends half an hour after it on the tenth, and he writes $a l-' \bar{a} s h \bar{u} r \bar{a}$ ' and not al- 'āshūr (al-Bīrūnī 1878, pp. 276-277). ${ }^{4}$

So far, al-Wațwāt relied on al-Maqdisī and al-Bīrūnī in his account of the Day of Atonement. Although he borrowed some content from his predecessors, he is original in part of it, as far as I am able to ascertain. As a condition for breaking the fast, he says, one must see three stars. The Jews, he adds, believe that this day marks the end of Moses's forty-three-day fast (al-Wațāt 1990, Vol. 1, p. 217), probably in reference to Deut. 9:18, in which a forty-day fast is reported: "And I fell down before the Lord, as at the first, for forty days and forty nights: I neither ate bread nor drank water because of all your sins that you sinned, in doing wickedly in the sight of the Lord, to provoke Him to anger." ${ }^{, 5}$ Furthermore, he writes that the fast will not fall on Sunday, Tuesday and Friday (al-Wațāt 1990, Vol. 1, p. 217). His statement corre-

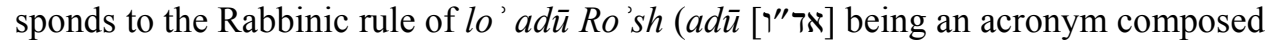
of the initials representing the first [ $\kappa]$, fourth [7], and sixth [1] days of the week), according to which Ro'sh ha-Shanah must not fall on these days (Maimonides 2008, p. 279 [7:1]; Abudraham 1963, p. 305).

Al-Wațât adds that, according to the Jews' belief, on this day Allāh forgives all their sins excluding fornication with married women (muhsanāt), exploitation, and disbelief in Him (al-Wațwāt 1990, Vol. 1, p. 217). Here too, he follows al-Maqdisī (al-Maqdisī 1907, Vol. 4, p. 37).

The Festival of Booths: Titled $i d$ al-mizalla a a literal translation of the Festival of Booths (hag ha-Sukkōt). Al-Wațāt claims that it lasts seven days. The first day, he says, is the fifteenth of Tishrei and the last day is called 'arābā, i.e., shajar alkhiläf, the willow tree (al-Wațāt 1990, Vol. 1, p. 217). Notably, 'Arabahah refers to the habitat ha- 'arabōt custom - pounding willow branches on the floor of the synagogue in a remembrance of a Temple rite - on the last day of Sukkōt, Hōsha 'nā Rabbah. This name is used in Jewish sources and sometimes appears as yawm 'Arabah (see e.g., Sìddūr Rab Sa 'adya Gaon 1963, pp. 239, 251; see further, Avishur 1997, pp. 340-341). It recurs, although with a slight difference, 'arāfā, in al-Äthār al-Bāqiya, a source that provides few details on the customs of the Jews on this day (al-Bīrūnī 1878, p. 277).

This is also their pilgrimage (hajj) time, al-Wațāt explains, probably referring to Exod. 23:14: "Three times shall you keep a festival (tahog) unto Me in the year." During this time, they sit under zilāl (lit. shadows) of green palm branches stripped

\footnotetext{
${ }^{3}$ On al-Bīrūn̄̄'s life and work and his account of Jewish festivals, see Boilot (1960); Schreiner (1886, pp. 263-266); Ratzaby (1990); Adang (1996b, pp. 92-93); de Blois (2014, pp. 71-72).

${ }^{4}$ It deserves mention that al-Bīrūnī's words on the execution are probably in reference to Lev. 23:29, which is partially misunderstood, and his comments about al-'āsh $\bar{u} r$ are probably in reference to Num. 29:7.

${ }^{5}$ Translation taken from The King James Version of the English Bible (1941). In certain cases, the translation is slightly modified to reflect (in my opinion) the Hebrew text more accurately.
} 
of their leaves (jarid al-nakhl), of olive branches, and of willow and other trees (alWațaàt 1990, Vol. 1, p. 217). From the context, it seems that in zilāl, al-Wațaatt refers to thatching (sekhakh). Support for this is found in the prayer book of R. Sa adya Gaon (882-942 CE), in which the same term for sekhakh is used (Sïddür Rab Sa 'adya Gaon 1963, p. 233). The most common sekhakh is an open palm frond. Jarìd al-nakhl in Hebrew is kappot temarim, which, according to Lev. 23:40 is one of the four species that one must procure for the Sukkott festival. In the Rabbinic tradition, it is identified as the lüla $\underline{b}$, a closed frond of the date palm (Maimonides 2008, 7:1 [p. 265]). If so, al-Wațwăt may have confused sekhakh with lūlab. As for the olive branches, they were probably used for decoration, being too short and thin to serve as sekhakh.

The Jews, al-Watwāt explains, say that dwelling in a booth reminds them of the shadows (azlā $l$ ) that Allāh provided their ancestors in the desert in the form of clouds (al-Wațwāt 1990, Vol. 1, p. 217). This is probably a reference by al-Wațwāt to the Pillar of Cloud ('amüd he-'anan), also known as the Clouds of Glory ('ananei hakaboōd) (e.g., JT Yōmā 2:1 [1:1]; Babylonian Talmud (BT) Ta 'anīt 9a; BT Ye $\underline{b} a m \bar{t} t$ 72a), a Biblical manifestation of God's presence (e.g., Exod. 13:21-22, 14:19, 33:910; Num. 12:5, 14:14, 31:15). In BT Sukkah 11a, a disagreement appears regarding the meaning of Lev. 23:42: "I made the Children of Israel to dwell in booths." R. Eli 'ezer claims that these booths were 'ananei ha-kabōod; R. 'Akiba interprets the word "booths" in its literal sense. Egyptian Rabbanites in al-Wațwāț's time (al-Wațwāț himself does not identify them as Rabbanite, but one presumes that they were, because he cites a Midrash) appear to have been familiar with this Midrash and to have favoured R. Eli 'ezer's view.

Passover: Titled 'id al-fațir, a literal translation of the Hebrew hag ha-Maș$s \bar{o} t$, the Festival of the Unleavened Bread, the Biblical term for Passover (Pesah) (e.g., Exod. 23:15). They call it, al-Wațwāt says, al-fash. It falls on the fifteenth of Nīsan and lasts seven days, during which they eat mașșah (fațīr) and clean their houses from leavened bread (khubz al-khamīr), because they believe Allāh saved the Israelites from Pharoah and drowned him on these days. Following this, he continues, they came out to the desert, ate meat and mașsōt, and celebrated (al-Wațwăt 1990, Vol. 1, p. 217). Here al-Wațwāț's account is basically identical to al-Maqdisı̄'s with one exception: al-Maqdisī calls the festival 'ìd al-fațīr only (al-Maqdisī 1907, Vol. 4, p. 37).

Pentecost: Al-Wațāt calls the festival 'ìd al-asābì ', a literal translation of hag ha-Shab $\bar{u}$ 'ot . This festival, he claims, occurs seven weeks after Passover (exactly as is written in Lev. 23:15), on the sixth of Sīvan (al-Wațaāt 1990, Vol. 1, p. 217). Al-Maqdisī also presents such information, describing the festival very briefly without mentioning its date (al-Maqdisī 1907, Vol. 4, p. 37). Al-Wațwāt continues by reporting that the Jews say that Allāh spoke with the Israelites at Mount Sinai on this day. Pentecost, he specifies, is one of the Jews' three pilgrimage festivals, together with Passover, and Sukkōt (al-Wațaat 1990, Vol. 1, p. 217). Here he refers to Exod. 23:14-17, which speak of the festival of the unleavened bread (mașsōt), the festival of the harvest (qașir), and the festival of the ingathering of the grain (asîf). Al-Wațaât 
identifies all three correctly. ${ }^{6}$ He adds that the Jews venerate Shab $\bar{u}$ ' $\bar{o} t$, observing it by eating dumplings ( $\left.q a t \bar{a}^{\top} i f\right)$ and claiming that they are a substitute for manna (alWațwāṭ 1990, Vol. 1, p. 217).

Al-Wațāt mentions two additional names for this festival which he probably learned from the Jews of his time: 'îd al-khitâab and 'ìd al- 'anșara (al-Wațāt 1990, Vol. 1, p. 217). ${ }^{7}$ Both allude to the central event of this observance. The Jews, he reports, say that Allāh spoke (khātaba) with the Israelites from Mount Sinai on this day. Here he may have based himself on Deut. 4:12-13, which reports that in the revelation the Lord spoke (va-yedaber) and declared (va-yagged) His covenant unto the Israelites. Al-'anșara may be a corruption of the Hebrew ha- 'Așeret, given that another Hebrew name for Pentecost is hag ha- 'Așeret, the festival of the assembly (Mishnah Ro'sh ha-Shanah 1:2). The name al-'anșara is used in Jewish sources (see e.g., Sìddūr Rạb Sa'adya Gaon 1963, pp. 155-156; Gil 1983, Vol. 3, p. 104 [letter no. 460, TS 13 J 6, f. 22]; Allony 2006, p. 407 [list no. 108, TS K 3.42]; see further, Ashtor 1944, Vol. 2, p. 380). He may, however, have learned about it from al-Bīrūnī (1878, p. 281) who also used it.

Purim: This is the festival that al-Wațāt describes at the greatest length. After titling it 'i $\bar{l} d$ al-für, he says that the Jews innovated it, ${ }^{8}$ indicating that he draws a distinction between the Written and the Oral Law (although Purim originates in the Bible and not the Oral Law). His view of the origin of this festival also explains why his overview of the festival cycle is chronologically discontinuous. He adds that they call it al-fürayā (الفوريا) (al-Wațāt 1990, Vol. 1, p. 217). Here al-Wațwāṭ uses a term

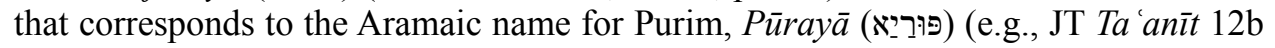
[2:12]; JT Megillah 6a [1:14]; BT Megillah 7b; BT Sanhedrin 12b), which was also in use in the Geonic period (7th-11 th centuries CE).

Al-Watwāt then explains the background of the festival: Nebuchadnezzar (Bukhtnașar) exiled the Israelites from Jerusalem and settled them in Ișfahān. During the reign of Ardashīr b. Bābik, ${ }^{9}$ king of Persia, whom the Jews call Ahashverōsh (Ahshārūsh), his vizier, Haman (Haymūn) envied Mordecai (Mardūkhāy), the Jewish sage (habr), because the king had married Mordecai's cousin (i.e., Esther according to the Biblical account, although al-Wațāt does not mention her by name). Therefore, Haman planned to execute the Jews in the middle of Adar (i.e., the fifteenth of the month - the Biblical source refers to the thirteenth of the month as the time of the intended massacre [Esth. 3:13]). He chose this day because the Jews believed that on this day Moses was born and passed away and he meant to cause them even more sorrow (al-Wațwāt 1990, Vol. 1, p. 218). Here al-Wațaāt is wrong about the date, but it seems that he absorbed something about these occasions. After all, the date of Moses's

\footnotetext{
${ }^{6}$ Notably, al-Bīrūnī (1878, p. 281) translated these verses into Arabic, but a comparison of both scholars' wordings makes it seem unlikely that al-Wațaāt relied on him.

${ }^{7}$ Interestingly, Pentecost has also many names in the Jewish tradition. See Halperin (1994, p. 51.)

${ }^{8}$ The expression "innovated" denotes a festival of Rabbinic provenance.

${ }^{9}$ Ardashīr b. Bābik was a Sassanid king (226-241 CE). The reason for identifying Ardashīr with Ahashverōsh deserves a separate study.
} 
birth and death is mentioned in the Talmud (BT Megillah 13b; BT Nazīr 14a) as well as in Seder 'Ōlam Rabbā (Neubauer 1895, Vol. 2, pp. 40-41; Milikowsky 2013, Vol. 2:10, p. 249), a 2nd-century CE Jewish chronology ascribed to R. Jose son of Halaftā (BT Niddah 46b), as the seventh of Adar. Another possibility is that he borrowed from al-Bīrūnī (1878, p. 280) who reports that Haman (which he writes as Hāmān) asked the magicians to specify the worst time for the Jews. They replied: "Adar, [when] Moses their teacher died. The most unfortunate days for them are fourteenth and fifteenth of it" (al-Bīrūnī relies here on BT Megïllah 13b).

Al-Wațật continues: Mordecai discovered Haman's scheme, brought it to the attention of his cousin who accordingly planned a stratagem (hilla) to save the Jewish people. She advised the king of the vizier's jealousy of Mordecai and of his plan. The king had the vizier and the members of his household executed and issued a writ of protection (amān) for the Jews. Therefore, they celebrate this day and fast three days before it (al-Wațaāt 1990, Vol. 1, p. 218). Here al-Wațwāt is inspired by Esth. 4:16: "Go, gather together all the Jews that are present in Susa (Shūshan), and fast for me, and neither eat nor drink three days [...]." It is possible that he describes a custom among the Karaites, who follow the Biblical text literally, ${ }^{10}$ since Rabbanites observe only a one-day fast, on the thirteenth of Adar (the Fast of Esther, ta 'anit Ester) (see Mirsky 1964, Vol. 2, p. 222 [79]). Support for this proposition comes from another Egyptian historian, Taqī al-Dīn Aḥmad b. 'Alī al-Maqrīzī (1364-1442 CE), who clearly states that the Karaites in Egypt fast from the thirteenth to the fifteenth (al-Maqrīzī 2003, Vol. 4/2, p. 946). ${ }^{11}$

Ever since, he continues, the Jews celebrate and rejoice, including the exchange of gifts (al-Wațāt 1990, Vol. 1, p. 218). This is probably a reference to the "sending of portions to one another" (the mishlōhei manōt - Esth. 9:19, 22). Thus far, al-Watwāt's description matches the Biblical narrative. However, he does not mention the scroll reading (qerī'at megīllah), the giving of alms (mattanōt la- 'ebiōnīm), and the feasting (mishteh) that are obligatory on this day according to the Rabbinic teachings (see Mishnah Megïllah 1:4; JT Megïllah 6b; [1:4]; BT Megïllah 7a; JT Sheqalìm 1a [1:1]). Finally, al-Wațāț writes that the Jews produce an effigy (șüra) of Haman, fill its belly with dates, and then burn it (al-Wațwâț 1990, Vol. 1, p. 218). He may have learned about this from al-Bīrūnī who describes a similar act (al-Bīrūnī 1878, pp. 280-281). Notably, such a custom was known in earlier periods and in various Jewish communities. $^{12}$

Hanukkah: Al-Wațāṭ calls this festival al-hanukka and says that it, too, is something that the Jews innovated. It lasts eight days. On the first night the Jews (probably referring to the Rabbanites, since the Karaites do not acknowledge Hanukkah) light one candle (sirāj) at the gates of their houses and so on until they light eight on the eighth night (al-Wațāṭ 1990, Vol. 1, p. 218).

\footnotetext{
${ }^{10}$ Some Karaite sources claim that the fast of Esther is not obligatory. See Bashyachi (1966, p. 157).

${ }^{11}$ On al-Maqrīzī’s life and work and his account of Jewish festivals, see Rosenthal (1991); Rabbat (2003); Bauden (2010; 2013; 2014); Mazuz (2019a).

${ }^{12}$ See further, Holder (1986, p. 195).
} 
Hanukkah, he says, is celebrated because one of the jabäbira took over the Temple, killed those who were there, and invoked the ius primae noctis privilege. The sons of the priest attacked him and the youngest of them killed him. They searched for oil for the Temple, but found only a small quantity. They divided it commensurate with the number of candles that they light every night at the doorways of their houses during the eight nights and established them as days of festival and called it Hanukkah. This word [al-hanukka] is derived from the word for cleaning (tanziff), since during these days they cleaned the sanctuary [of the Temple] from the dirt of the jabbārr's people (al-Wațwāt 1990, Vol. 1, p. 218). Al-Bīrūnī preceded alWațaat in using the word tanzîf to explain the meaning of the word Hanukkah, but did not elaborate on it (al-Bīrūnī 1878, p. 278). Al-Wațwāt's explanation is correct. Hanūkkah in Hebrew means inauguration. I Mac. 4:58 states that Judah ordered the celebration of hanukkkat ha-mizbeah, the inauguration of the altar, after the Maccabees purified it of the defilement that the Greeks had inflicted on it. The word jabäbira can be translated in several ways (Lane 1980, Vol. 2, p. 374). The most relevant in this context are heroes, tyrants, and mighty ones. Here al-Wațwāt may have absorbed some terminology from the 'al ha-nissim prayer, which Rabbanites recite on Hanukkah (and Purim) to thank God for His miracles and for delivering "the mighty (gībbōrimm) into the hands of the weak" (e.g., Sìddūr 'Abōdat Ha-Shem 2008, pp. 131-132; Sìddūr Yeheveh Da 'at 1995, pp. 80-81).

Possible inspiration from Talmudic sources also exists in al-Wațwāṭ's account of Hanukkah. The ius primae noctis motif appears in several sources. JT Ketūbōt 5b (1:5) states that the Greeks "decreed that the governor first have intercourse [with newly married women]." In BT Shabbat 23a, R. Joshua says that women are obliged to light the Hanukkah candle because they also experienced a miracle: the Greeks ruled that every virgin bride must have intercourse with the ruler before doing so with her husband; R. Joshua added that the miracle was made by a woman. ${ }^{13} \mathrm{R}$. Joshua may have been referring to the story of Mattathias's daughter. It is more likely, however, that al-Wațwāt was inspired by Midrash Ma 'aśeh Hanūkkah, according to which Mattathias's daughter, Hanna, tore her clothes on her wedding day in front of the guests, prompting her brothers to wish to kill her. Observing their rage, she asked them why her act should anger them since she is going to be given to the Greek governor. She then instructed them to take an example from Jacob's sons, Simon and Levi. They took her to the governor, who thought that they had come to surrender her, and when they entered his house they killed him (Eisenstein 1915, p. 190; Jellinek 1967, Vol. 1, pp. 2-3). Notably, al-Bīrūnī cites a background story for celebrating Hanukkah that has motifs similar to those in al-Wațāt's account, but the story is different as is the reason for celebrating eight days (al-Bīrūnī 1878, p. 278).

Al-Wațāt concludes his account of Hanukkah and all the festivals in the following words: "And some of them call it al-tabrīk" (al-Wațwāt 1990, Vol. 1, p. 218). The connection between al-tabrīk and Hanukkah is not clear. Al-Bīrūnī, one of al-

\footnotetext{
${ }^{13}$ The claim that virgin brides had to have intercourse with the Greek governor first occurs in BT Ketūbōt 3b.
} 
Wațwāṭ sources of information on Jewish festivals, also mentions a festival that is called al-tabrīk. He argues, however, that it falls on the twenty-second of Tishrei. The date and parts of his description of the festival (al-Bīrūnī 1878, p. 277) suggest that he refers to Simhat Tōrah. (The name tabrikk very likely stems from the name of the last weekly Torah reading that is central in the ritual of the Simhat Tórah festival, veZo't ha-Berakhah.) The presence of this observation in al-Wațāț's account of Hanukkah is difficult to explain and deserves further study.

\section{Al-Wațāạt's Influence on Ensuing Muslim Descriptions of Jewish Observances}

The account under discussion (as well as other contents in al-Wațaāṭ's Mabāhij) had an influence on later encyclopaedic treatises on the Mamluk period. Frédéric Bauden notes that although Ahmad b. 'Abd al-Wahhāb al-Nuwayrī (1272-1332 CE), ${ }^{14}$ a younger contemporary of al-Wațāt's, did not quote his source in the account of Jewish festivals in his Nihäyat al-Arab fi Funūn al-Adab, it may be identified as alWațwāṭ. He further claims that al-Maqrīzī in al-Mawā'iz wa'l-I'tibār fì Dhikr alKhitat wa'l-Äthär undoubtedly relied on al-Nuwayrī, noting as proof the phrasing and the order in which the festivals are detailed (Bauden 2006, pp. 132-133). Al-Maqrīzī discusses, inter alia, Jewish festivals at least three times: twice in al-Khitat (al-Maqrīzī 2003, Vol. 4/2, pp. 942-948, 951-952), and once in al-Khabar 'an al-Bashar fí Ansāb al- Arab wa-Nasab Sayyid al-Bashar (al-Maqrīzī, n.d.). ${ }^{15}$ When the texts are placed side-by-side, Bauden's statement regarding al-Maqrīzì's reliance on al-Nuwayrī appears better suited to al-Maqrīzī's description of the festivals in al-Khabar than it does to that in al-Khitaț. ${ }^{16}$

Both al-Nuwayrī and al-Maqrīzī elaborated on al-Wațâț's account. While the former added only few sentences and words (see al-Nuwayrī 1923, Vol. 1, p. 195), the latter significantly expanded this account as it pertains to Sukkot, Passover, Pentecost, Purim, and Hanukkah (see Mazuz 2019a; 2019b). Another Muslim scholar who relied on al-Wațwāṭ's account of Jewish festivals is Aḥmad b. 'Alī al-Qalqashandī (ca. 1355-1418 CE) in his Subh al-A 'shā fí Șinā at al-Inshä'. In fact, al-Qalqashandī copied al-Wațāt's entire account. Even though his wording is somewhat different in reference to a few of the festivals, the identity of his source is unmistakable (see alQalqashandī 1922, Vol. 2, pp. 426-429). It is evident, then, that al-Wațwāṭ’s description of the major Jewish festivals established a basis for inquiries that were copied and expanded in later generations by other Muslim scholars who were interested in Egyptian Jews and their religious customs.

\footnotetext{
${ }^{14}$ On his life and work, see Chapoutot-Remadi (1995).

${ }^{15}$ See further, Frenkel (2012, pp. 329-333); Mazuz (2019a; 2019b).

${ }^{16}$ For additional cases in which al-Maqrīzī’s words are taken from al-Nuwayrī, who relied on al-Wațaāt, see Mazuz (2017, pp. 5, 8).
} 


\section{Conclusion}

Three additional points in al-Wațwāṭ's account of Jewish festivals are noteworthy: (1) His stress is on the essence of each festival. (2) He does not mention Rabbanites or Karaites. (3) The names that he uses for the festivals are noteworthy: sometimes he gives the literal translation, sometimes the name itself, and in others the Aramaic form, as appears in the Talmud. This shows either an effort by mediaeval Muslim scholars to translate the names of Jewish festivals in the closest possible manner to their Hebrew forms or to use the names that Jews in the Islamic world invoked for their festivals.

Al-Wațāț's account of Jewish festivals is a conflation of parts of the descriptions of al-Maqdisī and al-Bīrūnī along with some Jewish content. ${ }^{17}$ Al-Maqdisī's overview covers only five Jewish festivals and four fasts and appears as part of his description of the Jewish faith and customs; al-Bīrūnī, in contrast, references the full set of observances in a chapter that describes the entire Jewish calendar. The questions of why al-Wațaat took from each the parts that he took and why he describes only seven festivals remain unanswered.

Although it contains some inaccuracies and misunderstandings, al-Waṭwāt's account corresponds rather closely to the Rabbinic approach. As for the specific Jewish sources (textual or oral) that underlie his text, no unequivocal answer can be given. Part of his description may have been inspired by his familiarity with some aspects of Jewish life in Egypt of his time. Alternatively, given that al-Wațaaț was a wealthy bookseller (hence his name: al-Kutubī, "the Bookseller"), he may have derived his knowledge about Jewish festivals from some of the many books to which he was exposed.

Despite the slightly polemical tenor of his claim that Purim and Hanukkah are innovations, his account lacks polemical purposes or tendencies. Therefore, alWațāt enriches our knowledge of the religious, and to some extent the spiritual, lives of the Rabbanite Jews of Egypt in the 13th and 14th centuries CE. No less important is that his remarks about the festivals serve as a basis for inquiry on the topic for later mediaeval Muslim scholars who promote this knowledge, and their reports, side-byside with Jewish sources, give us the most complete picture of the topic that can be attained.

\section{References}

Abudraham, D. (1963): Sefer Abudraham ha-Shalem. Jerusalem, 'Ūshā Press.

Adang, C. (1996a): Judaism and the Bible in al-Maqdisī's Kitāb al-Bad' wa 'l-Ta'rīkh. In: LazarusYafeh, H. (ed.): Muslim Authors on Jews and Judaism: The Jews among Their Muslim Neighbors. Jerusalem, The Zalman Shazar Center for Jewish History, pp. 59-68 [in Hebrew].

${ }^{17}$ Jewish contents are intertwined in some of al-Maqdisī’s and al-Bīrūn̄̄’s writings, providing examples of Jewish materials that were recycled in Islamic literature (and then recycled again by later Muslim scholars). 
Adang, C. (1996b): Muslim Writers on Judaism and the Hebrew Bible: From Ibn Rabban to Ibn Hazm. Leiden, E.J. Brill.

Allony, N. (2006): The Jewish Library in the Middle Ages: Book Lists from the Cairo Genizah (Oriens Judaicus, Series I, Vol. III). Edited by Frenkel, M.-Ben-Shammai, H., with the participation of Sokolow, M. Jerusalem, Ben Zvi Institute [in Hebrew].

Ashtor, E. (1944): History of the Jews in Egypt and Syria under the Mamlüks, 3 vols. Jerusalem, Rabbi Kook Institute [in Hebrew].

Avishur, Y. (1997): Remarks on Names for Sabbath or Festival Eves in the Judaeo-Arabic of the East. Leshonenu Vol. 60, pp. 335-342 [in Hebrew].

Bashyachi, E. (1966): Aderet Eliyahu. Ramla, National Council of Karaite Jews in Israel.

Bauden, F. (2006): Maqriziana I: Discovery of an Autograph Manuscript of al-Maqrīzī: Towards a Better Understanding of His Working Method Description: Section 2. Mamlūk Studies Review Vol. 10, No. 2, pp. 81-139.

Bauden, F. (2010): s.v. al-Maqrīzì. In: Dunphy, R. G. (ed.): Encyclopedia of the Medieval Chronicle. Leiden-Boston, E.J. Brill, pp. 1074-1076.

Bauden, F. (2013): al-Maqrīzī. In: Thomas, D.-Mallett, A. (eds): Christian-Muslim Relations: A Bibliographical History. Volume 5 (1350-1500). Leiden, E.J. Brill, pp. 380-395.

Bauden, F. (2014): Taqī al-Dīn Aḥmad ibn 'Alī al-Maqrīzī. In: Mallett, A. (ed.): Medieval Muslim Historians and the Franks in the Levant. Leiden, E.J. Brill, pp. 161-200.

Bīrūn̄̄, al-, M. (1878): Kitāb al-Āthār al-Bāqiya 'an al-Qurūn al-Khāliya. Edited by Sachau, C. E. Leipzig, Brockhaus.

Boilot, D.J. (1960): s.v. al-Bīrūnī. In: Encyclopaedia of Islam (2nd Edition), 12 vols. Leiden, E.J. Brill, Vol. 1, pp. 1236-1238.

Chapoutot-Remadi, M. (1995): s.v. al-Nuwayrī. In: Encyclopaedia of Islam (2nd Edition), 12 vols. Leiden, E.J. Brill, Vol. 8, pp. 156-160.

de Blois, F. (2014): Some Early Islamic and Christian Sources Regarding the Jewish Calendar (9th-11th Centuries). In: Stern, S. - Burnett, Ch. (eds): Time, Astronomy, and Calendars in the Jewish Tradition. Leiden, E.J. Brill, pp. 65-78.

Eisenstein, J. D. (ed.) (1915): Ozar Midrashim: A Library of Two Hundred Minor Midrashim. New York, n.p. [in Hebrew].

Frenkel, Y. (2012): Al-Maqrīzī on Jewish Festivals. In: Gruber, M. I. - Brenner, A. - Garsiel, M. Levine, B. A. - Mor, M. (eds): Teshura le-Zafrira: Studies in the Bible, the History of Israel and the Ancient Near East Presented to Zafrira Ben-Barak. Be'er Sheba, Ben-Gurion University of the Negev Press, pp. 325-343 [in Hebrew].

Ghersetti, A. (2013): On Mamluk Anthologies Again: The Case of Jamāl al-Dīn al-Wațāṭ and His Ghurar al-Khașā'iṣ al-Wādihah wa- 'Urar al-Naqā'iḍ al-Qābihah. Mamlūk Studies Review Vol. 17, pp. 72-99.

Ghersetti, A. (2015): A Pre-Modern Anthologist at Work: The Case of Muhammad b. Ibrāhīm alWațwāṭ (d. 718/1318). In: Behzadi, L. - Hämeen-Anttila, J. (eds): Concepts of Authorship in Pre-Modern Arabic Texts. Bamberg, University of Bamberg Press, pp. 23-45.

Gil, M. (1983): Palestine during the First Muslim Period (634-1099), 3 vols. Tel Aviv, Tel Aviv University and the Ministry of Defense Publishing House [in Hebrew].

Halperin, B. (1994): The Different Meanings of Pentecost. Beit Mikra: Journal for the Study of the Bible and Its World Vol. 39, No. 1, pp. 51-62 [in Hebrew].

Holder, M. (1986): History of the Jewish People: From Yavneh to Pumbedisa. New York, Mesorah Publications.

Jellinek, A. (ed.) (1967): Beit ha-Midrash, 6 vols. Jerusalem, Wahrmann Books. 
The King James Version of the English Bible: An Account of the Development and Sources of the English Bible of 1611 with Special References to Hebrew Tradition. Chicago, University of Chicago Press, 1941.

Lane, E.W. (ed.) (1980): Arabic-English Lexicon, 8 vols. Beirut, Librairie du Liban.

Lazarus-Yafeh, H. (ed.) (1996): Muslim Authors on Jews and Judaism: The Jews among Their Muslim Neighbors. Jerusalem, The Zalman Shazar Center for Jewish History [in Hebrew].

Maimonides, M. (2008): Mishneh Torah. An Exact Edition based on Original Manuscripts, with Indexes. Edited by Makbili, Y. - Kara, Y.-Gershoni, H. Haifa, Rabbi Kook Institute.

Maqdisī, al-, M. (1907): Kitāb al-Bad' wa'l-Ta'rīkh, 6 vols. Edited and translated by Huart, Cl. Paris, Ernest Leroux.

Maqrīzī, al-, A. (n.d.): al-Khabar 'an al-Bashar fì Ansāb al-'Arab wa-Nasab Sayyid al-Bashar, Vol. 1, pp. 181-186, MS. Istanbul Süleymaniye Kütüphanesi - Aya Sofya 3362.

Maqrīzī, al-, A. (2003): al-Mawā'iz wa'l-I'tibār fì Dhikr al-Khițat wa'l-Āthār, 4 vols. Edited by Sayyid, A. F. London, Al-Furqān Islamic Heritage Foundation.

Mazuz, H. (2017): Post-Biblical Jewish Sources in al-Maqrīzī’s Historiography - Whence His Knowledge? Journal of Arabic and Islamic Studies Vol. 17, pp. 1-13.

Mazuz, H. (forthcoming, 2019a): The Jewish Calendar and Calendation according to al-Maqrīzī in al-Khitat. Zeitschrift der Deutschen Morgenländischen Gesellschaft Vol. 169.

Mazuz, H. (forthcoming, 2019b): Al-Maqrīzī on Jews and Judaism in al-Khitat: Remarks and Insights. Bein 'E $\underline{b} e r$ le- 'Arab Vol. 11 [in Hebrew].

Milikowsky, C. (ed.) (2013): Seder Olam, 2 vols. Jerusalem, Ben Zvi Press.

Mirsky, S. K. (ed.) (1964): She' ìltōt de-Ra $\underline{b}$ Aḥa, 5 vols. Jerusalem, Sura Institute, Yeshiva University Press, and Rabbi Kook Institute.

Neubauer, A. (ed.) (1895): Seder 'Ōlam Rabbā in Medieval Jewish Chronicles and Chronological Notes, 2 vols. Oxford, Clarendon Press [in Hebrew].

Nuwayrī, al-, A. (1923): Nihāyat al-Arab fì Funūn al-Adab, 21 vols. Cairo, Maṭba at Dār al-Kutub al-Mașrī.

Qalqashandī, al-, A. (1922): Șubh al-A 'shā fí Sinā'at al-Inshā', 3 vols. Cairo, Dār al-Kutub alMașriyya.

Rabbat, N. (2003): Who Was al-Maqrīzī? A Biographical Sketch. Mamlūk Studies Review Vol. 7, No. 2, pp. 1-19.

Ratzaby, Y. (1990): Megīllat Ta anīt Șaddīqīm in an Arabic Source. Sinai Vol. 106, pp. 1-11 [in Hebrew].

Rosenthal, F. (1991): s.v. al-Maqrīzì. In: Encyclopaedia of Islam (2nd Edition), 12 vols. Leiden, E.J. Brill, Vol. 6, pp. 193-194.

Schreiner, M. (1886): Les Juifs dans al-Beruni. Revue des études juives Vol. 12, pp. 258-266.

Sìddūr 'Abōodat Ha-Shem (2008). Holon, n.p.

Sìddūr Rạ Sa 'adya Gaon: Kitāb Jāmi al-Șalawāt wa'l-Tasābīh (1963). Edited by Davidson, I.Assaf, S. - Yoel, I. B. Jerusalem, Meḳize Nirdamim.

Sìddūr Yeheveh Da 'at (1995). Jerusalem, Yeheveh Da' at Institute.

Waardenburg, J. (ed.) (1999): Muslim Perceptions of Other Religions: A Historical Survey. New York-Oxford, Oxford University Press.

Wațwāṭ, al-, M. (1990): Mabāhij al-Fikar wa-Manāhij al- 'Tbar, 2 vols. Edited by Sezgin, F. Frankfurt am Main, Institute for the History of Arabic-Islamic Science at the Johann Wolfgang Goethe University. 
